\title{
A hero with a butterfly net
}

\section{Anthill: A Novel \\ by E. O. Wilson \\ Norton: 2010.384 pp. $\$ 24.95$}

Raff is the main character in Anthill, the first novel by the towering entomologist Edward O. Wilson. As a child, Raff lives in a world in which nearly everything is decided for him, either by his parents or by chance. He feels like an insect in the lawn - a tiny creature surrounded by big trees and adults. His hard-drinking father is only occasionally employed. His mother believes that she has chosen the wrong man and, in doing so, the

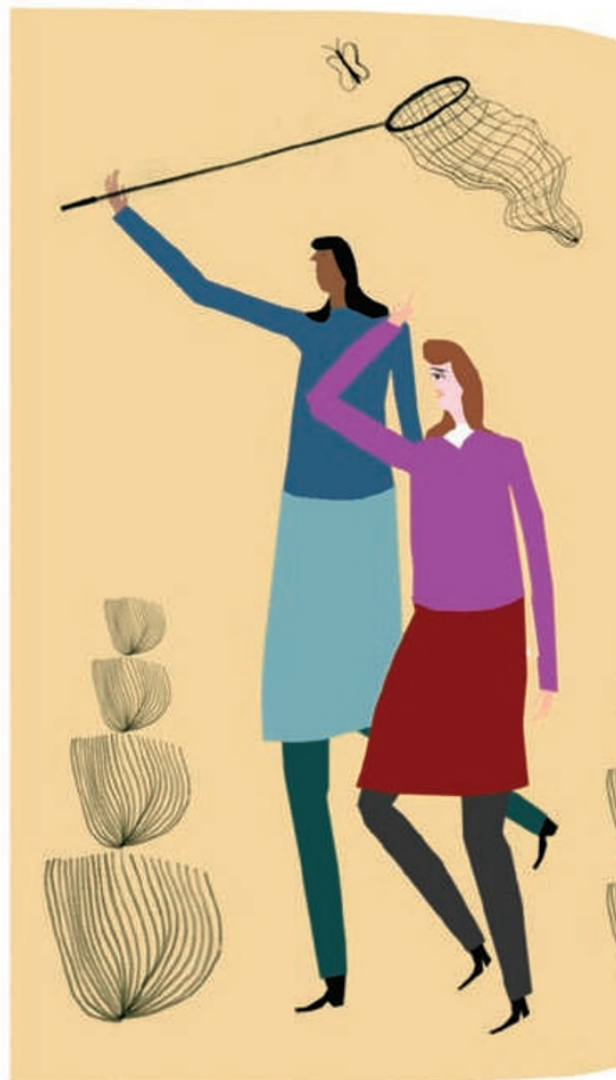

wrong life. The most likely fate for Raff is a middling persistence, setting down one leg at a time on an almost inevitable path. But nature intervenes.

As a boy, Raff spends days and nights in a marshy pine forest across town from his house. That swamp changes Raff. He makes it his - an untamed land to know and to map. At first it seems to be an entire world, wild enough to hold a big alligator and thousands of unnamed forms of life. As he grows, the swamp shrinks, and what was once endless comes under threat from development. But Raff cares for the crooked trees and stinky water as much as he cares for any place or thing in the world. Soon he finds himself, against the wishes of nearly everyone around him, walking in the 'wrong' direction on the welltrodden track.

Raff fights for the swamp. His battle takes him to Harvard Law School and then to a job at the very company that plans, in the long term, to develop the swamp. And so the story unfolds; or rather, two stories unfold. Beneath Raff's story is a tale of ants, a second society beneath the leaves. The ant protagonist is a colony of an introduced species that grows unchecked, beyond reason and resources, like the introduced fire ants that Wilson discovered at the age of 13 at a dock in Mobile, Alabama. Their explosion mirrors the human story of suburban growth and 'progress' that Raff is pitted against. The ants do not provide a moral; they simply echo the seemingly inexorable expansions of our own colonies into every habitable land. It is this creeping inevitability from which Raff must break free.

Anthill is the latest in a long line of Wilson's accomplishments. With his friend Bert Hölldobler, he wrote The Ants (Harvard University Press, 1990), the definitive book on ants. He also founded the field of sociobiology, which begat evolutionary psychology. But for me, Wilson's greatest achievement is that, like Carl Sagan, he has given us a view of the grandeur of the Universe. He sees life, with his one good eye, more vividly than other people. Fortunately, he shares his lens. "Have you seen this?" he seems to say. "Come over here and take a look."

Wilson the novelist is no different, and Anthill also invites us to look carefully at the living world. Raff gives voice to Wilson's view of life. Indeed Wilson, like his protagonist, found inspiration and refuge in ants, had a favourite swamp, became an eagle scout, and ended up at Harvard University.

The book is filled with details of the living world. Here and there, as a dragonfly darting to a pond, Wilson is drawn to things that catch his eye. Sometimes describing them in too much depth, he immerses us in their richness. Yet the analogies between ant and human societies are deep, and only by revealing their intricacies can Wilson show how the fates of ants and young men can, sometimes, diverge. Ants, the details seem to urge, are like us - but at least we, like Raff, can exercise free will.

As a boy, Wilson would surely have loved this book. It casts him as a kind of small-town hero, with butterfly net and snake stick, rather than gun and cape. I can only hope that such a figure becomes a plausible hero for my children and their generation.

Anthill is a story about how one child can, inspired by the natural world, grow up to make a difference. We live in a time when the power of individuals seems to be shrinking, rather

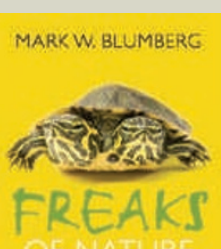

rever now wivident
Freaks of Nature: And What They Tell Us About Evolution and Development by Mark W. Blumberg (Oxford Univ. Press, $£ 8.99$ ) Evolutionary theory, argues Mark Blumberg, must move away from the orthodox, gene-centred view of evolution. Jerry Coyne wrote: "By presenting a parade of animal 'freaks' - mutants, developmental anomalies and weird species - Blumberg imparts lessons that, although familiar to biologists, will be valuable to nonspecialists." (Nature 457, 382-383; 2009.)

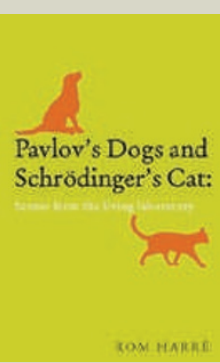

Pavlov's Dogs and Schrödinger's Cat: Scenes From the Living Laboratory

by Rom Harré (Oxford Univ. Press, E8.99)

Scientists use various creatures to study life. Rom Harré takes us through 500 years of the 'living laboratory' to show how organisms have been used in scientific discovery. "This charming book is entertaining, thought-provoking and frustrating. It is worth reading for all three of those reactions." (Andrew Read, Nature 458, 1113-1114; 2009.) 
than growing - making us seem more and more like ants. In such times, we need hopeful books like this and more heroes such as Raff or Wilson.

Robert Dunn is an ecologist in the Department of Biology at North Carolina State University, Raleigh, North Carolina 27695, USA. He is the author of Every Living Thing: Man's Obsessive Quest to Catalog Life, from Nanobacteria to New Monkeys. e-mail:rob_dunn@ncsu.edu

\section{Under the skin of climate change}

\section{Solar \\ by lan McEwan \\ Jonathan Cape: 2010. 304 pp. \\ $\$ 26.95, £ 18.99$}

Following his 2005 novel Saturday, in which the central character is a neurosurgeon, in his latest book celebrated British author Ian McEwan explores the personal side of the science and politics of climate change. A sophisticated work of fiction, Solar is littered with references to physics and engineering. Its intention, however, is to show scientists as social actors beyond the idealized stereotype.

McEwan's narrative follows British theoretical physicist Michael Beard from 2000 to 2009 , a decade when the world is adjusting to the perspective of anthropogenic climate change. Beard has already been anointed with the "magic dust" from Stockholm - the Nobel prize. His productive research is behind him; he has turned instead to chasing women and converting his magic dust into money by taking up advisory jobs. Beard is a good observer, an intelligent and clever man.

The story focuses not on global warming itself but on how Beard turns the opportunities that arise to his own ends. As a consequence, he changes. He starts out "not wholly sceptical", unimpressed by suggestions "that humankind was drifting towards calamity". He opines that "the end of the world was never pitched in the present, where it could be seen for the fantasy it was". Later, he adopts a different position: "The planet is sick. Curing the patient is a matter of urgency and is going to be expensive". The question of the book is how this transformation takes place.

The answer is through both need and opportunity. Beard's attentions are redirected after he meets the young, idealistic postdoc Tom Aldous, who pushes the idea of using photosynthesis on an industrial scale to produce clean energy. Aldous pleads with Beard to read his proposals - without success. But after Aldous meets his fate on a polar-bear rug,

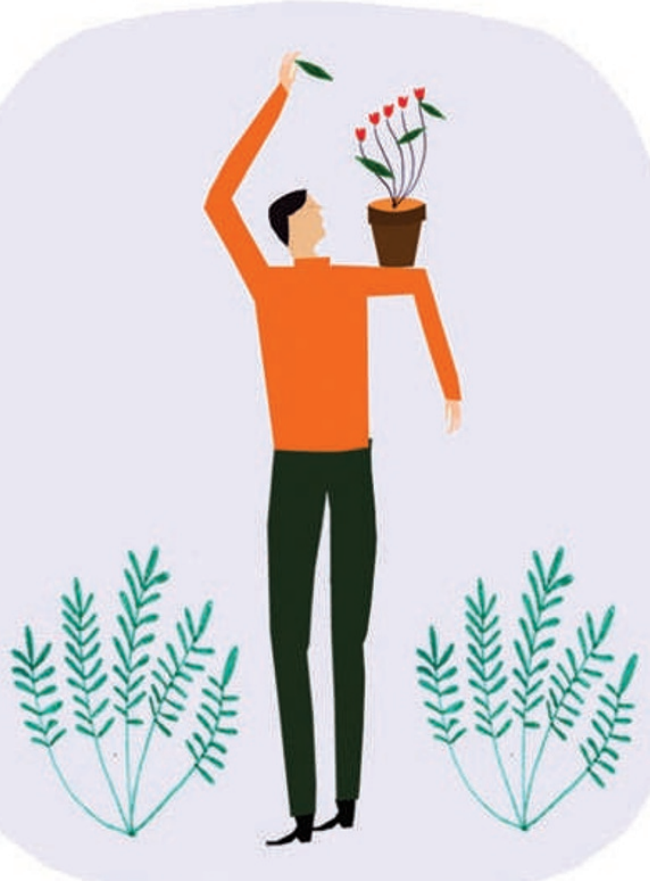

Beard does eventually look into the postdoc's files. In them he spots a blueprint for making money - lots of money - and for gaining an even greater reputation.

Beard establishes a consortium and, after the remaining scientific and technical problems are solved, builds a small demonstration plant in New Mexico. He persuades his investors of the urgency of producing clean energy but assures them that they will "get rich along the way". He encourages sceptical co-workers with remarks such as: "Here's the good news. The UN estimates that already a third of a million people a year are dying from climate change." Or, equally cynically: "It's a catastrophe. Relax!" But in the end, Beard's quest doesn't solve his problems - legal, medical or personal.

Although the plot is simplistic and the ending unconvincing, Solar is an interesting character study. McEwan's description of a fictional scientist who has received the ultimate award but who suffers from that very recognition is apt; Beard pays his 'Nobel price' by no longer being allowed to work as an ordinary scientist. He is smart enough to know that he cannot save the world, but he is also clever and unscrupulous enough to take a chance and jump on the climate-change bandwagon.

Solar is not a wake-up call for the public to take climate change seriously; nor does it serve sceptics who consider climate change a hoax. It is not a static stage on which wooden characters declare some preconceived truth, as in the sciencefiction film The Day after Tomorrow (2004) and the Michael Crichton thriller, State of Fear (HarperCollins, 2004). Instead, it is a book about climate change as a social construct in the real world. It is especially appropriate at a time when the motivations of climate scientists are under scrutiny.

Hans von Storch is a director at the Institute of Coastal Research of the GKSS Research

Centre, D-21502 Geesthacht, Germany, and a member of the KlimaCampus of the University of Hamburg, D-20146 Hamburg, Germany. e-mail:hvonstorch@web.de

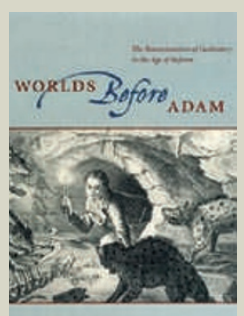

namisnows
Worlds Before Adam: The Reconstruction of Geohistory in the Age of Reform

by Martin J. S. Rudwick (Chicago Univ. Press, E22.50)

This history of Earth science reveals that the emergence of modern geology was "comparable in its cultural impact with that of relativity or Darwinian evolution", wrote reviewer Victor Baker. "Rudwick highlights an underappreciated, glorious advance in human thought, the documentation of which is a rather glorious achievement in itself." (Nature 454, 406-407; 2008.)

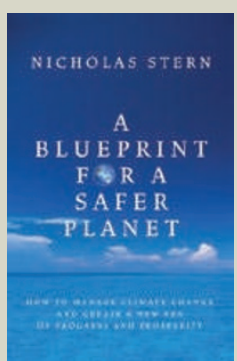

A Blueprint for a Safer Planet: How We Can Save the World and Create Prosperity by Nicholas Stern (Vintage, $£ 8.99$ ) Economist Nicholas Stern lays out a road map for managing the climate crisis, describing the dangers of climate change and examining possible responses. "Stern presents an up-to-date, logically argued synthesis, using a style that makes his book more intelligible than many others on the topic." (Robert Costanza, Nature 458, 1107-1108; 2009.) 